\title{
Apoptosis in the pathogenesis of infectious diseases of the eastern oyster Crassostrea virginica
}

\author{
Inke Sunila $^{1, *}$, Jill LaBanca ${ }^{2}$ \\ ${ }^{1}$ State of Connecticut, Department of Agriculture, Bureau of Aquaculture, PO Box 97, Milford, Connecticut 06460, USA \\ ${ }^{2}$ Fairfield University, 1073 North Benson Road, Fairfield, Connecticut 06430, USA
}

\begin{abstract}
Apoptosis, or programmed cell death, has been reported as being pivotal in infectious diseases of different organisms. The effects of apoptosis on the progression and transmission of the protistan parasites Perkinsus marinus and Haplosporidium nelsoni in the eastern oyster Crassostrea virginica were studied. Oysters were diagnosed for their respective infections by standard methods, and apoptosis was detected using in situ hybridization to detect DNA fragments by end labeling on paraffin sections. A digoxigenin nucleotide probe was used to label the $200 \mathrm{bp}$ fragment produced by apoptosis and detected immunohistochemically using an antidigoxigenin peroxidase conjugate. The probe/DNA fragment complex was stained with a peroxidase substrate and tissues were counterstained with methyl green. Uninfected oysters had large numbers of apoptotic hemocytes present in the connective tissue underlying the stomach, gill, and mantle epithelia, whereas oysters infected with $P$. marinus had a reduced number of apoptotic hemocytes. The parasite may prevent hemocyte apoptosis in order to yield a greater number of hemocytes in which to house itself. Large numbers of $P$. marinus cells in some infected oysters were eliminated via apoptosis in the stomach epithelia, disabling the spread of infectious particles through seawater. The oysters infected with $H$. nelsoni also had reduced numbers of apoptotic hemocytes, while part of the vesicular connective tissue cells were apoptotic. H. nelsoni plasmodia were eliminated via apoptosis in some oysters. Apoptosis may enhance progression and prevent transmission of infectious oyster diseases.
\end{abstract}

KEY WORDS: Apoptosis · Haplosporidium nelsoni $\cdot$ Perkinsus marinus $\cdot$ In situ hybridization Resale or republication not permitted without written consent of the publisher

\section{INTRODUCTION}

Apoptosis, also called programmed cell death, is a natural part of the animal cell cycle, as well as an important factor in the progression of animal diseases. In a healthy animal, apoptosis usually occurs when a cell is damaged, infected, senescent, or otherwise of little use to the animal. Some pathogens enter a cell and inhibit apoptosis to increase their life span (Cuff \& Ruby 1996). Other pathogens enter a cell and induce apoptosis in order that they might spread their infection to other cells (Fugier-Vivier et al. 1997). Although the end result of apoptosis is cell death, the mechanism is different from necrosis. Necrosis causes a cell to erupt its contents, triggering an inflammatory response. Apoptosis is a more controlled reaction that does not induce inflammation (Barr \& Tomei 1994).
When a cell undergoes apoptosis, the cell shrinks and rapid blebbing, also called zeiosis, occurs (Sanderson 1982). The nucleus of the cell then collapses and the chromatin condenses, forming crescent shapes. Chromatin changes are due to endonucleases, which digest DNA in multiples of 180 to 200 base pair (bp) (Arends et al. 1990). These fragments can be visualized by agarose gel electrophoresis as the classical 'DNA ladder'. The cell breaks into apoptotic bodies; smaller bodies containing some nuclear and cellular contents and part of the plasma membrane. The apoptotic bodies are often phagocytized before they lyse in an attempt to prevent further spread of infectious agents (Cohen et al. 1992). Neighboring cells tend to become phagocytic to prevent the loss of important nutrients.

A common method for detecting apoptosis is the TdTmediated dUTP-biotin nick end-labeling, or TUNEL 
method. This method utilizes an enzyme, terminal deoxynucleotidyl transferase (TdT), to anneal digoxigenin-nucleotides to the exposed ends of apoptotic DNA (Schmitz et al. 1991, Gavrieli et al. 1992), labeling the 180 to $200 \mathrm{bp}$ fragment yielded by apoptosis. An anti-digoxigenin peroxidase antibody conjugate then binds to the digoxygenin-nucleotide and is observed after treatment with a chromogenic peroxidase substrate, which creates a distinguishable stain for immunohistochemical detection (Gavrieli et al. 1992).

Infectious diseases are recognized as a major problem in the culture of the eastern oyster Crasssostrea virginica. Two important diseases, commonly called 'Dermo' and 'MSX' (Multinucleated Sphere X), have caused chronic high mortalities in Mid-Atlantic states (Chesapeake and Delaware Bays) and seriously threaten oyster populations in New England states (Ewart \& Ford 1993). Dermo was first described by Mackin et al. (1950) as a fungal infection (Dermocystidium marinum) of the eastern oyster, but the causative agent, Perkinsus marinus, is currently classified as an apicomplexan. It is responsible for high oyster mortalities from the Gulf of Mexico to Delaware Bay (Craig et al. 1989) and has been present in Long Island Sound since 1991 (Brousseau et al. 1998, Karolus et al. 2000).

MSX disease, caused by the parasite Haplosporidium nelsoni, is another economically important oyster disease. It was first detected in the lower Delaware Bay in 1957 (Haskin et al. 1965, 1966, Ford \& Haskin 1982) and can now be found along the eastern United States from Biscayne Bay, Florida to Damariscotta River, Maine (Haskin \& Andrews 1988). H. nelsoni caused great mortality of Crasssostrea virginica in the Connecticut and New York shorelines of Long Island Sound in 1985 (Haskin \& Andrews 1988), and again in 1997 (Sunila et al. 1999).

Although there are numerous publications about these economically important oyster diseases, their pathogenesis is not fully understood. Study of apoptosis rests upon early research on invertebrates. The first gene whose expression is involved in regulating cell death (Ced-3), was described in the nematode Caenorhabditis elegans (Miura et al. 1993). Apoptosis is a key factor in infectious diseases (Thompson 1995). In this paper we describe the role of apoptosis in 2 economically important, infectious oyster diseases. This is the first report describing apoptosis of host cells or parasites in the field of molluscan pathology.

\section{MATERIALS AND METHODS}

Since 1997 oyster samples have been collected for routine monitoring from Long Island Sound, located between New York and Connecticut in the northeastern United States. Perkinsus marinus infection was determined with the Ray/Mackin tissue assay in Ray's fluid thioglycollate medium (RFTM; Ray 1954) and the intensity of the infection was determined by weighted prevalence on the Mackin scale from 0 (uninfected) to 5 (heavy) according to Mackin (1962). Tissues were preserved in Davidson's fixative (in 20\% artificial seawater) and embedded in paraffin. Tissue sections $(6 \mu \mathrm{m})$ were stained with H\&E and examined for the presence of Haplosporidium nelsoni. The severity of $H$. nelsoni infection was histologically determined to be 1 of 4 stages - an initial infection, an intermediate infection, an advanced infection, or a terminal infection (Farley 1968). We established 4 categories for the purpose of this study: mature oysters with no infections (size $[x]=89.5 \mathrm{~mm}, \mathrm{SD} 12.05)$, juvenile oysters with no infections ( $x=21.9 \mathrm{~mm}$, SD 6.79), oysters infected with only $P$. marinus ( $x=94.1 \mathrm{~mm}, \mathrm{SD} 15.03)$ and oysters infected with only $H$. nelsoni $(x=76.1 \mathrm{~mm}$, SD 21.6). Oysters with any other pathological changes listed by Sunila (2000) were excluded from this study. These changes included inflammatory responses, degenerations, cell and tissue death, growth derangements, hemodynamic and fluid derangements and neoplasia. The oysters infected with $P$. marinus had weighted prevalences ranging from 0.5 to 4.0 , and all the oysters infected with $H$. nelsoni had terminal infections. Ten oysters from each category were selected to undergo in situ hybridization, using Apoptag ${ }^{\circledR}$, a peroxidasebased apoptosis detection kit (Intergen Company).

Tissue sections $(6 \mu \mathrm{m})$ were placed on silanated slides. The sections were deparaffinized and rehydrated through ethanol before being brought to phosphate buffered saline (PBS). The tissues were then pretreated with Proteinase $\mathrm{K}\left(20 \mu \mathrm{g} \mathrm{ml} \mathrm{m}^{-1}, 15 \mathrm{~min}\right.$, room temperature) and $0.1 \%(\mathrm{w}: \mathrm{v})$ Triton X-100 in PBS (10 min). They were quenched in $3 \%$ hydrogen peroxide in PBS for $5 \mathrm{~min}$, rinsed in water, and treated with equilibration buffer. The tissues were then incubated with TdT and nucleotides $\left(1 \mathrm{~h}, 37^{\circ} \mathrm{C}\right)$. After incubation, the tissues were treated with stop/wash buffer, followed by an anti-digoxigenin peroxidase conjugate (30 min, room temperature). After a wash in PBS, tissues were stained with a peroxidase substrate. Tissues were counter-stained in a $0.5 \%(\mathrm{w}: \mathrm{v})$ methyl green solution. The specimens were dehydrated and mounted. The positive control was normal female rat mammary gland after weaning of pups, included in the Apoptag $^{\circledR}$ kit. For one negative reaction control, TdT was substituted with water, while the other negative reaction control consisted of staining rehydrated slides with peroxidase substrate without adding TdT or antibody conjugate to detect possible endogenous peroxidase activity. 
(A)

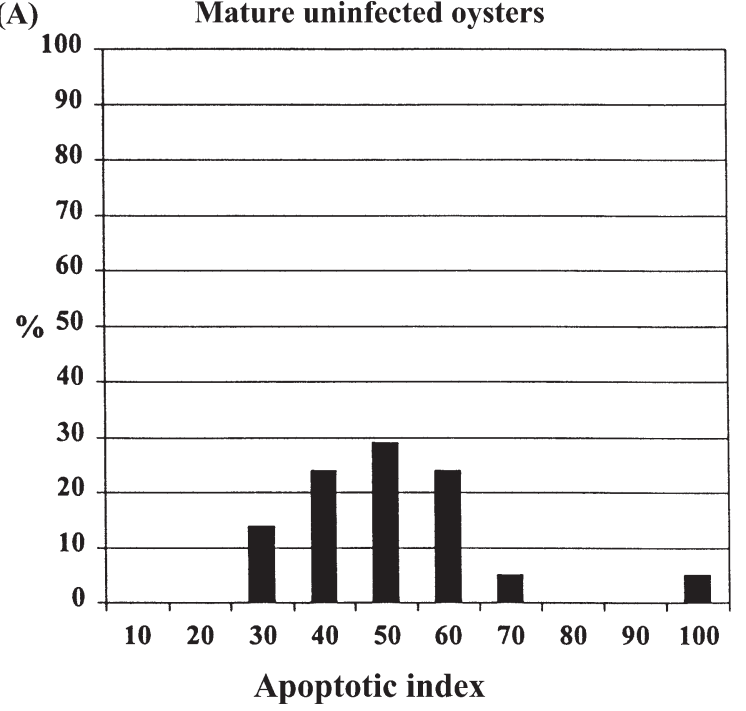

Fig. 1. Apoptotic indexes of hemocytes in eastern oysters Crassostrea virginica. Apoptosis was detected by in situ hybridization using Apoptag ${ }^{\circledR}$ on paraffin sections. Apoptotic indexes (see text for details) plotted against percentage of specimens with the index. (A) Mature, uninfected oysters; (B) oysters infected with Perkinsus marinus; (C) oysters infected with Haplosporidium nelsoni

Apoptotic indexes were used to quantify differences in the number of apoptotic cells. The ratio of apoptotic cells to live cells was determined as follows:

$$
\text { Apoptotic index }=\frac{\text { No. of apoptotic cells }}{\text { Total no. of cells }} \times 100
$$

This index was applied to apoptotic hemocytes, Perkinsus marinus and Haplosporidium nelsoni cells. A minimum of 100 cells were examined per slide (a minimum of 1000 cells per category).

The number of apoptotic vesicular connective tissue cells was compared between Haplosporidium nelsoniinfected and healthy specimens. It was determined by calculating the total number of apoptotic vesicular connective tissue cells in the entire cross-section of an oyster.

The Mann-Whitney (Wilcoxon) $W$-test was used for statistical purposes.

\section{RESULTS}

In situ hybridization with Apoptag ${ }^{\circledR}$ produces brown apoptotic cells with light green counterstain. Several different cell types were observed undergoing apoptosis in the oyster tissues: hemocytes, columnar epithelial cells of the stomach and intestine, vesicular connective
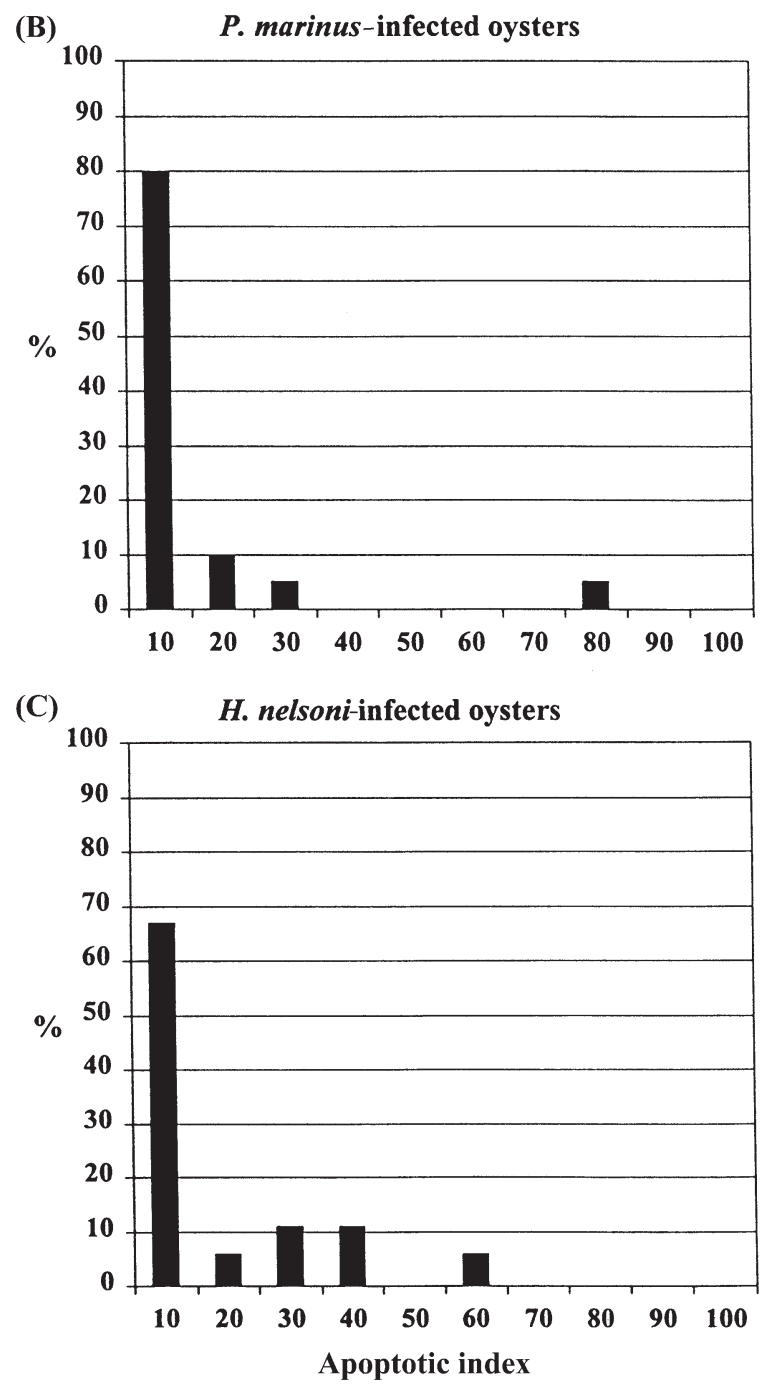

tissue cells, digestive cells of the digestive tubules, ciliated cells of the digestive ducts, germinal epithelial cells, ciliated gill epithelial cells, and muscle fibers of the adductor muscle and the heart. Perkinsus marinus and Haplosporidium nelsoni plasmodia were apoptotic in some oysters. The numbers and types of apoptotic cells differed between juvenile and mature oysters and between infected and uninfected oysters.

\section{Uninfected oysters}

In mature uninfected oysters, the most common apoptotic cell type was hemocyte. Apoptotic indexes of hemocytes varied significantly between uninfected, Perkinsus marinus-infected and Haplosporidium nelsoni-infected oysters (Fig. 1). Apoptotic indexes in the control specimens varied from 23 to $99(x=46.0$, SD 16.2). Apoptotic hemocytes were observed in the 

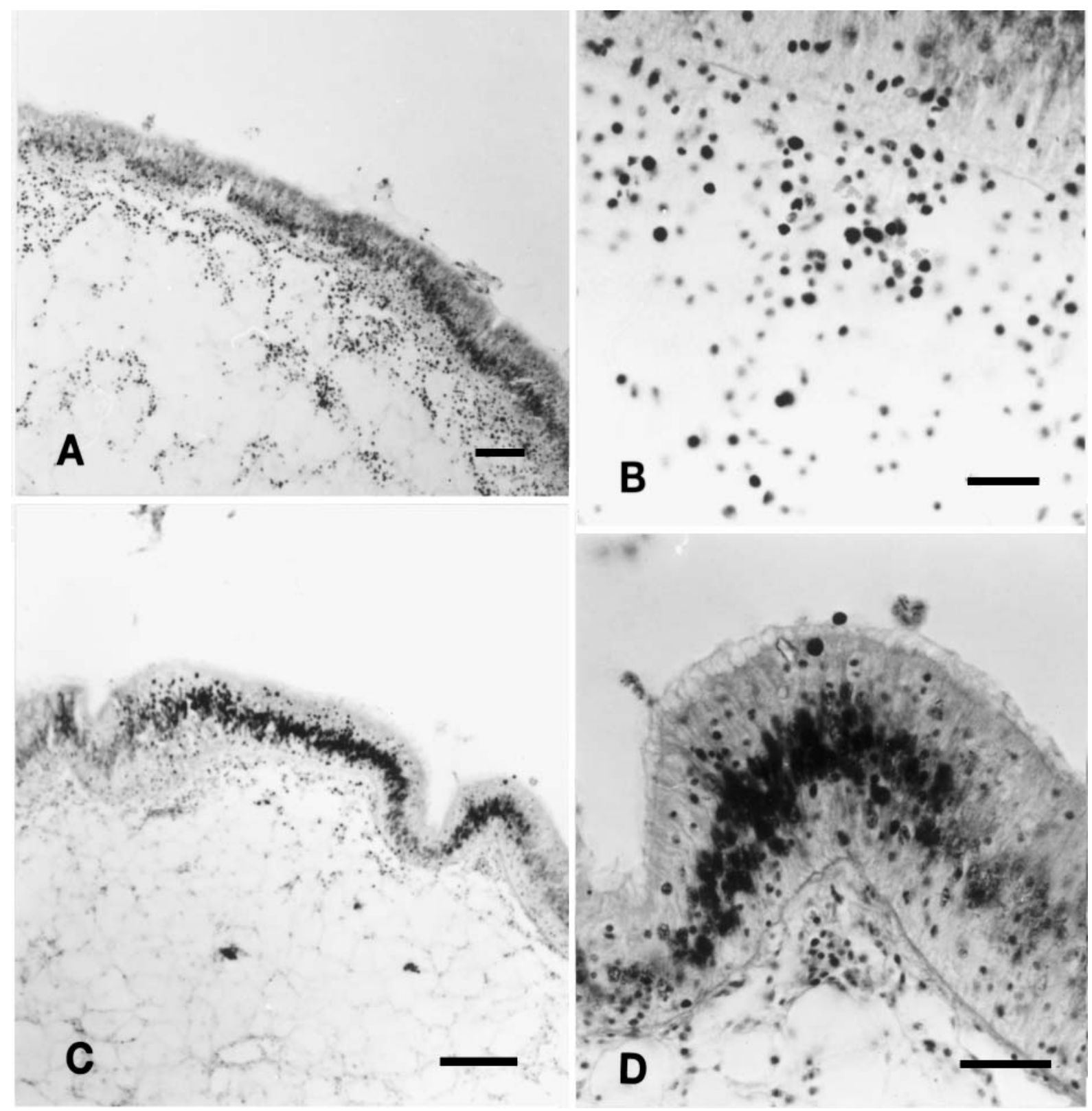

Fig. 2. In situ hybridization with Apoptag ${ }^{\circledR}$ for detecting apoptotic cells in eastern oysters Crassostrea virginica. All panels show mature, uninfected oysters. (A) Stomach epithelium and underlying connective tissue. Apoptotic hemocytes appear as dark dots in the connective tissue. Scale bar $=100 \mu \mathrm{m}$. (B) Higher magnification of (A). Apoptotic hemocytes appear as dark, round bodies, live hemocytes as grey, irregularly shaped cells. Scale bar $=50 \mu \mathrm{m}$. (C) Segment of apoptotic stomach epithelium. Apoptotic epithelial cells stain dark, live epithelial cells light gray on both sides. Scale bar $=100 \mu \mathrm{m}$. (D) Higher magnification of (C) Dark staining apoptotic epithelial cells with live, light grey staining cells on the right. Scale bar $=50 \mu \mathrm{m}$

connective tissue underlying the stomach and intestine epithelia (Fig. 2A,B). They were also present in the connective tissue of the mantle and gills. When hemocytes were observed in diapedesis in stomach, intestine or mantle epithelia, they were frequently apoptotic. Part of the epithelial cells of the stomach and intestine were apoptotic in some specimens. Apoptosis typically was observed within a limited area of the epithelium (Fig. 2C,D). In addition, ciliated gill epithelial cells were observed to be apoptotic in limited areas and some germinal epithelial cells were apoptotic (not shown).

The juvenile uninfected oysters had a greater occurrence and variety of apoptotic and mitotic cells than mature oysters. As in the mature oysters, apoptotic 

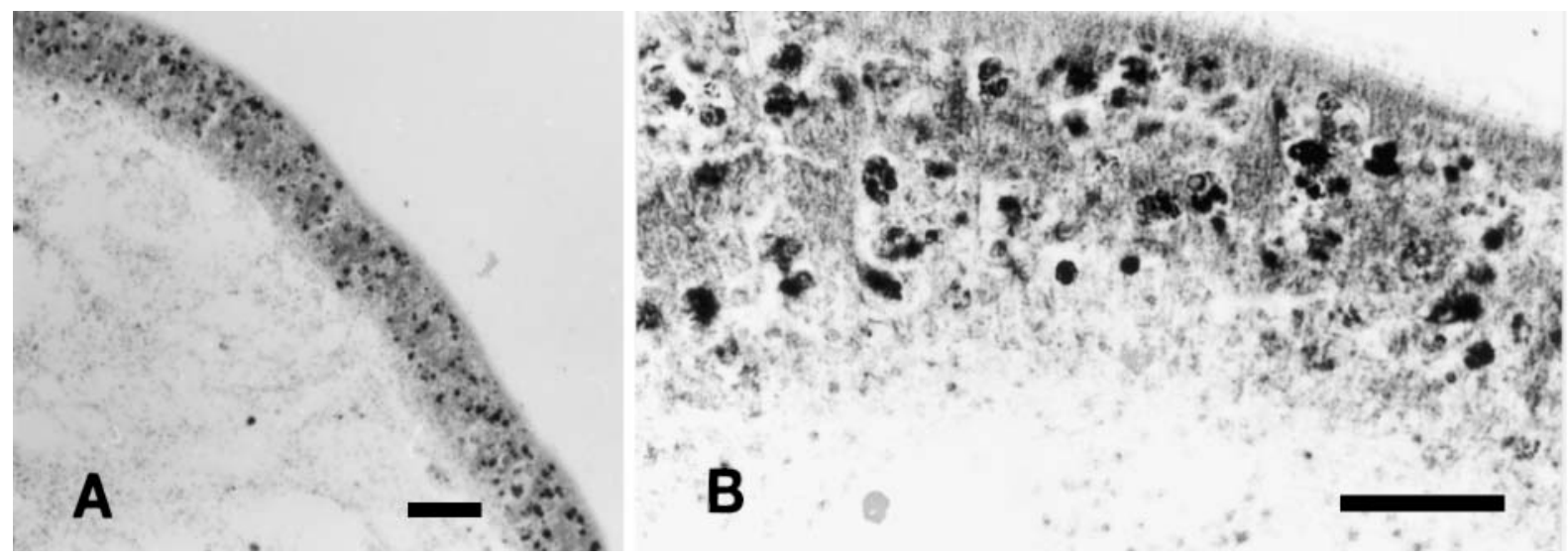

Fig. 3. In situ hybridization with Apoptag ${ }^{\circledR}$ for detecting apoptotic cells in eastern oysters Crassostrea virginica. All panels show Perkinsus marinus infected oysters. (A) Stomach epithelium ladden with dark staining, apoptotic P. marinus cells. Scale bar = $100 \mu \mathrm{m}$. (B) Higher magnification of (A). Apoptotic P. marinus cells can be seen among the epithelial cells. Single trophonts as well as daughter cells within a schizont can be seen. Scale bar $=50 \mu \mathrm{m}$

hemocytes were present surrounding the stomach and intestine. The gills had apoptotic epithelial cells in limited areas and apoptotic hemocytes in hemolymph sinuses. There were apoptotic muscle fibers among live muscle fibers in the adductor muscles and in the heart, and apoptotic endothelial cells in the vascular system (not shown). Some digestive tubule and duct cells were observed undergoing apoptosis, while some others were undergoing mitosis.

\section{Oysters infected with Perkinsus marinus}

There was significantly less apoptosis of granular hemocytes in oysters infected with Perkinsus marinus ( $W=21.0, \mathrm{p}<0.001$, Fig. 1B). The hemocyte apoptotic indexes varied from 0 to $79(x=9.9$, SD 17.4). Apoptosis of any other oyster cell types did not differ from the controls. P. marinus cells were usually detected at the stomach and intestine epithelia. They appeared as single trophonts or schizonts where several daughter cells were within a common schizont wall. There were apoptotic $P$. marinus cells in all 10 oysters (Fig. 3A,B). Apoptosis targeted either a single daughter cell of a schizont or all daughter cells simultaneously. Apoptotic $P$. marinus cells in the intestine and stomach epithelia appeared exclusively within phagocytic hemocytes. Apoptotic P. marinus cells were also seen passing through palp and mantle epithelia. Apoptotic P. marinus cells inside phagocytic hemocytes were also observed in the connective tissue underlying the mantle and the intestine. The ratio of apoptotic $P$. marinus cells to live $P$. marinus cells varied between specimens. The $P$. marinus apoptotic index ranged from 13 to 100 $(x=46.4$, SD 25.24).

\section{Oysters infected with Haplosporidium nelsoni}

Oysters infected with Haplosporidium nelsoni had a significantly lower number of apoptotic granular hemocytes than the control oysters $(W=26.5, \mathrm{p}<$ 0.001). Apoptotic indexes varied from 0 to $55(x=11.0$, SD 16.2, Fig. 1C). Infected oysters selected for this study represented terminal infections, and plasmodia were present throughout the tissues. In 9 of the 10 specimens some of the plasmodia were apoptotic (Fig. 4A). Apoptotic plasmodia were phagocytized by hemocytes. However, most of the plasmodia were live and the percentage of apoptotic plasmodia generally low. The $H$. nelsoni apoptotic indexes varied from 0 to $7(x=3$, SD 2.29). There were more apoptotic vesicular connective tissue cells (VCTC, Fig. 4B) in the H. nelsoni-infected oysters than in the control oysters ( $W=$ 103.5, p < 0.001). In the control oysters, apoptosis of VCTC were found in only one specimen; in the infected oysters there were apoptotic VCTC in all but one specimen. The number of apoptotic VCTC on a section in $H$. nelsoni-infected specimens varied from 0 to 89 (mean $=18.8$, SD 26.6). The number of apoptotic VCTC in control specimens varied from 0 to $2(x=0.18$, SD 0.6).

\section{DISCUSSION}

Apoptotic hemocytes were present in oysters, presumably playing a role in the hemocyte renewal process. Hemocytes in diapedesis were often apoptotic. However, the number of apoptotic hemocytes in the connective tissue underlying the stomach and intestine epithelia was magnitudes higher than the num- 

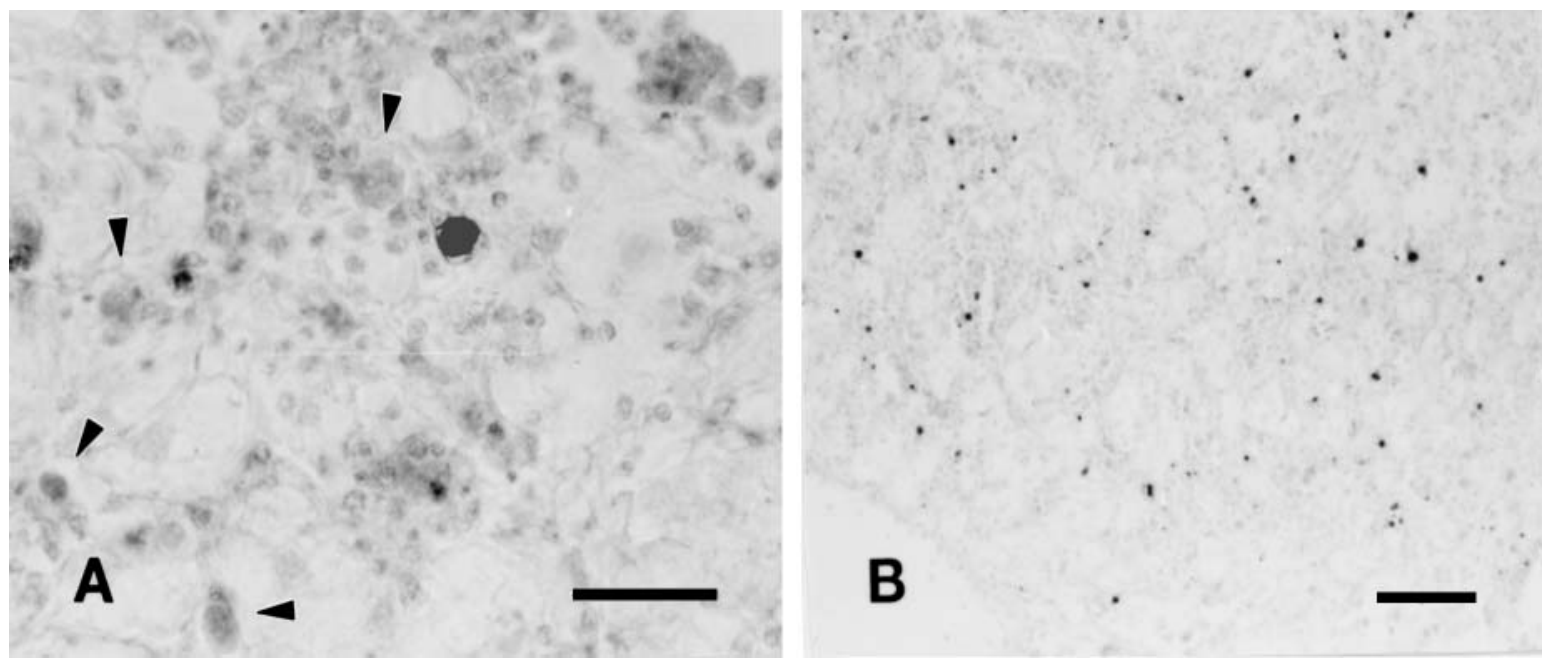

Fig. 4. In situ hybridization with Apoptag ${ }^{\circledR}$ for detecting apoptotic cells in eastern oysters Crassostrea virginica. All panels show Haplosporidium nelsoni-infected oysters. (A) Single apoptotic, dark staining H. nelsoni plasmodium in the middle of the photograph. Arrowheads point to live $H$. nelsoni plasmodia. Scale bar $=50 \mu \mathrm{m}$. (B) Apoptosis of vesicular connective tissue cells. Apoptotic cells appear as dark staining dots. Scale bar $=100 \mu \mathrm{m}$

ber of apoptotic hemocytes in diapedesis, suggesting that only a small portion of apoptotic hemocytes are expelled from the oyster. Apoptosis of hemocytes in the connective tissue may be the mechanism of recycling old hemocytes. The observation of hemocyte recycling is in accordance with results obtained in mammalian studies where leukocyte apoptosis is a major mechanism controlling leukocyte counts (Barcinski \& DosReis 1999). Some stomach and intestine epithelial cells were also apoptotic (Fig. 2C,D). Apoptosis of intestine epithelium is well documented in mammals, where the turnover rate of these cells is high (Gavrieli et al. 1992). In rats, for example, cells proliferate at the lower part of the crypt and migrate up the villus towards the lumen. As the cells move, they differentiate and eventually die via apoptosis (Gavrieli et al. 1992). In oysters, however, apoptosis of epithelia occurred segment by segment. This phenomenon might keep the stomach and intestine functional while repair is performed in a limited area. Although we could not find published information about the life span of epithelial cells of the oyster intestine, based on the frequent occurrence of apoptosis and mitosis in these cell types, we can presume a fast turnover rate.

Oysters infected with Perkinsus marinus or Haplosporidium nelsoni had reduced numbers of apoptotic hemocytes (Fig. 1B,C). P. marinus cells occurred phagocytosed by hemocytes in the oysters of the present study. It has been reported that as many as half of the parasites may be contained within hemocytes. Some parasites appear to be destroyed within the phago- cytes, but others continue to develop within host cells (Ford \& Tripp 1996). Prevention of apoptosis of hemocytes may benefit $P$. marinus by yielding higher numbers of hemocytes, which it can infect and in which it can proliferate. This scenario has been previously proposed by Moss et al. (1999), who suggested the parasite Leishmania donovani prolongs the life span of the macrophages it infects by suppressing apoptosis, maintaining for itself a reservoir of cells to infect. Scanlon et al. (1999) suggested that the microsporidia Nosema algerae prevents apoptosis of human lung fibroblasts to create an environment in which it can extend its growth and differentiation time. Williams (1994) proposed that the bacterium Bordetella pertussis suppresses apoptosis of macrophages to multiply for a prolonged period of time. Thus, prevention of hemocyte apoptosis in the oyster by $P$. marinus may promote disease progression.

The role of hemocyte apoptosis prevention in Haplosporidium nelsoni-infection is ambiguous. $H$. nelsoni-infected oysters had lower apoptotic indexes among granular hemocytes. Advanced H. nelsoni infections are characterized by systemic hyaline hemocyte infiltration (Farley 1968). H. nelsoni, unlike Perkinsus marinus, does not receive any obvious benefits from increasing hemocyte counts. However, hemopoiesis in oysters is not known. It is not clear whether granular and hyaline hemocytes represent 2 different ontogenetic stages of a single cell lineage, or different cell lineages (Cheng 1996). If hyaline hemocytes were 'spent' granular hemocytes, prevention of granular hemocyte apoptosis would eventually manifest as a 
hyaline hemocyte infiltration. If granular and hyaline hemocytes represent different cell lineages, their abundance in $H$. nelsoni-infected tissues could indicate the oyster's defense with both acute and chronic inflammatory responses, and could be independent of parasite signalling.

In histological sections, Perkinsus marinus cells are detected among stomach and intestine epithelial cells (Dungan \& Anderson 1993). According to Ford \& Tripp (1996), this is a source of infection to other oysters because parasites are shed into the gut and released in the feces. In the present study, $P$. marinus cells in the epithelia were frequently apoptotic (Fig. 3A,B). Phagocytosed, apoptotic $P$. marinus cells were excreted by diapedesis. These cells are not infectious, and apoptosis appears to provide a mechanism to prevent transmission of the disease from one oyster to another. Even during moderate to heavy infections (weighted prevalences 3 to 4 ), $P$. marinus cells were eliminated via apoptosis.

It has been reported that serious histopathological changes accompany Perkinsus marinus infection (Ford \& Tripp 1996). There is a significant increase in brown cells in the auricles and connective tissues. As the disease progresses, hemocytes, parasites, and digestive epithelia are sloughed into the lumina of the stomach and intestine. Hemolymph vessels become occluded by parasites and hemocytes, and there are occasionally ulcers formed at the mantle surface. Digestive tubule epithelial tissue atrophies and tissues lyse (Ford \& Tripp 1996). While prevalences of $P$. marinus in Long Island Sound are high (Karolus et al. 2000), no significant pathology or mortality has been detected (Sunila 2000). Since no data of apoptosis in P. marinus infection in other geographical locations exist, we cannot conclude whether elimination of $P$. marinus via apoptosis in the epithelium is a basic part of the parasite's life cycle or a phenomenon restricted to the Long Island Sound area.

Haplosporidium nelsoni plasmodia in some specimens were apoptotic. The number of apoptotic plasmodia found in the tissues was low. The exact transmission mechanism of $H$. nelsoni is not known. Direct transmission via spores is unlikely because of the rare occurrence of sporulation, and the presence of an intermediate host has been proposed (Haskin \& Andrews 1988). Regardless of the mechanism, apoptotic plasmodia are not able to transmit the disease. It would appear that apoptosis is able to suppress disease transmission of $H$. nelsoni as well.

There is evidence based on prevalences and field mortality data that oysters develop genetic resistance for Dermo disease. Genetic resistance for MSX disease has been described by Haskin \& Ford (1979) and Ford \& Haskin (1987). The exact mechanisms for resistance are not known. Resistant oysters become infected, but they appear to restrict parasite development and have higher survival rates than susceptible strains (Ford 1988). Apoptosis of the parasites could be the mechanism in disease resistance. Genetic regulation of apoptosis has been thoroughly studied. It is regulated mainly by genes from bcl- 2 and interleukin- $1 \beta$ converting enzyme (ICE) gene families (Williams 1994, Thompson 1995, Moss et al. 1999). Apoptosis is normally inhibited by bcl-2 and bcl-XL, but infecting parasites may have mechanisms to disable these genes, allowing apoptosis to occur. ICE is a protein closely related to the ced-3 protein, the protein responsible for apoptosis in Caenorhabditis elegans (Thompson 1995).

It should be noted that apoptotic Perkinsus marinus parasites in this study were within phagocytes. This is typical for all apoptotic bodies, which are immediately phagocytosed by neighboring cells (Cohen et al. 1992). However, it is possible that $P$. marinus cells undergo apoptosis before they are phagosytosed, or they undergo apoptosis inside the hemocytes. In oysters with progressive MSX disease, it has been reported that oyster hemocytes are unable to phagocytose plasmodia (Ford 1988). Apoptotic plasmodia in this study were phagocytosed by hemocytes. Apoptosis of plasmodia appears to give them characteristics to make them recognizable by host phagocytic cells.

There was increased apoptosis of vesicular connective tissue cells in the Haplosporidium nelsoni-infected oysters (Fig. 4B). At the end of MSX-disease, the death of an oyster occurs quickly. Oysters that are marketable with healthy looking meats may die suddenly a week later. The ultimate reason for death is not known, although apoptosis of connective tissue cells may contribute to the final tissue breakdown.

In conclusion, this study suggests that apoptosis may have an important role in the progression and transmission of oyster diseases. Further studies about parasite apoptosis in disease resistant versus susceptible oyster strains, as well as apoptotic in vitro interactions between host cells and cultured oyster parasites, are warranted.

Acknowledgements. We warmly thank John Karolus and John Volk from the Bureau of Aquaculture for providing a scientific home for this project. Shannon Kelly is acknowledged for reviewing the manuscript.

\section{LITERATURE CITED}

Arends MJ, Morris RG, Wyllie AH (1990) Apoptosis: the role of endonuclease. Am J Pathol 136:593-608

Barcinski MA, DosReis GA (1999) Apoptosis in parasites and parasite-induced apoptosis in the host immune system: a new approach to parasitic diseases. Braz J Med Biol Res 32:395-401 
Barr PJ, Tomei D (1994) Apoptosis and its role in human diseases. BioTechnology 12:487-493

Brousseau DJ, Guedes JC, Lakatos CA, Lecleir GR, Pinsonneault RL (1998) A comprehensive survey of Long Island Sound oysters for the presence of the parasite, Perkinsus marinus. J Shellfish Res 17:255-258

Cheng TC (1996) Hemocytes and functions. In: Kennedy VS, Newell RIE, Eble AF (eds) The eastern oyster: Crassostrea virginica. Maryland Sea Grant College, College Park, MD, p 299-333

Cohen JJ, Duke RC, Fadok VA, Sellins KS (1992) Apoptosis and programmed cell death in immunity. Annu Rev Immunol 10:264-293

Craig A, Powell EN, Fary RR, Brooks JM (1989) Distribution of Perkinsus marinus in Gulf coast oyster populations. Estuaries 12:82-91

Cuff S, Ruby J (1996) Evasion of apoptosis by DNA viruses. Immun Cell Biol 74:527-537

Dungan CF, Anderson BS (1993) Binding specificities of mono- and polyclonal antibodies to the protozoan oyster pathogen Perkinsus marinus. Dis Aquat Org 15:9-22

Ewart JW, Ford SE (1993) History and impact of MSX and Dermo diseases on oyster stocks in the northeast region. NRAC Fact Sheet 200 Northeastern Regional Aquaculture Center, North Dartmouth, MA, p 1-8

Farley CA (1968) Minchinia nelsoni (Haplosporidia) disease syndrome in the American oyster Crassostrea virginica. J Protozool 15:585-599

Ford SE (1988) Host-parasite interactions in eastern oysters selected for resistance for Haplosporidium nelsoni (MSX) disease: survival mechanisms against a natural pathogen. Am Fish Soc Spec Publ 18:206-224

Ford SE, Haskin HH (1982) History and epizootiology of Haplosporidium nelsoni (MSX), an oyster pathogen in Delaware Bay, 1957-1980. J Invertebr Pathol 40:118-141

Ford SE, Haskin HH (1987) Infection and mortality patterns in strains of oysters Crassostrea virginica selected for resistance to the parasite Haplosporidium nelsoni (MSX). J Parasitol 73:368-376

Ford SE, Tripp MR (1996) Diseases and defense mechanisms. In: Kennedy VS, Newell RIE, Eble AF (eds) The eastern oyster: Crassostrea virginica. Maryland Sea Grant College, College Park, MD, p 581-660

Fugier-Vivier I, Servet-Delprat C, Rivailler P, Rissoad MC, Liu YJ, Rabourdin-Combe C (1997) Measles virus suppresses cell-mediated immunity by interfering with the survival and functions of dendritic and T cells. J Exp Med 186:813-823

Gavrieli Y, Sheman Y, Ben-Sasson SA (1992) Identification of programmed cell death in situ via specific labeling of nuclear DNA fragmentation. J Cell Biol 119:493-501

Haskin HH, Andrews JD (1988) Uncertainties and speculations about the life cycle of the eastern oyster pathogen Haplosporidium nelsoni (MSX). Am Fish Soc Spec Publ 18:5-22

Editorial responsibility: Albert Sparks,

Seattle, Washington, USA
Haskin H, Ford SE (1979) Development of resistance to Minchinia nelsoni (MSX) mortality in laboratory-reared and native oyster stocks in Delaware Bay. Mar Fish Rev 41:54-63

Haskin HH, Canzonier WJ, Myhre JL (1965) The history of 'MSX' on Delaware Bay oyster grounds 1957-1965. Am Malacol Union Annu Rep 32:20-21

Haskin HH, Stauber LA, Mackin JA (1966) Minchinia nelsoni n sp. (Haplosporidia, Haplosporidiidae): causative agent of the Delaware Bay oyster epizootic. Science 153: 1414-1416

Karolus J, Sunila I, Spear S, Volk J (2000) Prevalence of Perkinsus marinus (Dermo) in Crassostrea virginica along the Connecticut shoreline. Aquaculture 183:215-221

Mackin JG (1962) Oyster disease caused by Dermocystidium marinum and other microorganisms in Louisiana. Publ Inst Mar Sci Univ Tex 7:132-229

Mackin JG, Owen HM, Collier A (1950) Preliminary note on the occurrence of a new protistan parasite, Dermocystidium marinum n.sp. in Crassostrea virginica (Gmelin). Science 111:328-329

Miura M, Zhu H, Rotello R, Hartwieg EA, Yan J (1993) Induction of apoptosis in fibroblasts by interleukin-1 $\beta$ converting enzyme, a mammalian homolog of the $C$. elegans cell death gene ced-3. Cell 75:653-660

Moss JE, Aliprantis AO, Zychlinski A (1999) The regulation of apoptosis by microbial pathogens. Int Rev Cyt 183:203-240

Ray SM (1954) Historical review of D. marinum and related forms. Rice Institute Pamphlet Special Issue, Houston, TX, p 3-26

Sanderson CJ (1982) Morphological aspects of lymphocyte mediated cytotoxicity. In: Clark WR, Golstein P (eds) Mechanisms of cell-mediated cytotoxicity. Plenum, New York, p 3-21

Scanlon M, Leitch GJ, Shaw AP, Moura H, Visvesvara GS (1999) Susceptibility to apoptosis is reduced in the microsporidiainfected host cell. J Eukaryot Microbiol 46:34S-35S

Schmitz GG, Walkter T, Seibl R, Kessler C (1991) Nonradioactive labeling of oligonucleotides in vitro with the hapten digoxygenin by tailing with terminal transferase. Anal Biochem 192:222-231

Sunila I (2000) Monitoring oyster health in Long Island Sound. In: Whitlatch RB, Wood-Martin JR (eds) Proc Fourth Biennial Long Island Sound Research Conference 1998, State University of New York, Purchase. The Connecticut Sea Grant Collage Program, Groton, CT p 83-93

Sunila I, Karolus J, Volk J (1999) A new epizootic of Haplosporidium nelsoni (MSX), a haplosporidian oyster parasite, in Long Island Sound, Connecticut. J Shellfish Res 18: $169-174$

Thompson CB (1995) Apoptosis in the pathogenesis and treatment of disease. Science 267:1456-1462

Williams GT (1994) Programmed cell death: a fundamental protective response to pathogens. Trends Microbiol 2: 463-464

Submitted: December 15, 2001; Accepted: February 15, 2003 Proofs received from author(s): August 12, 2003 